\title{
Ellagic acid inhibits IL-1 $\beta$-induced cell adhesion molecule expression in human umbilical vein endothelial cells
}

\author{
Ya-Mei $\mathrm{Yu}^{1}{ }^{*}$, Zhi-Hong Wang ${ }^{1}$, Chung-Hsien $\mathrm{Liu}^{2}$ and Chin-Seng Chen ${ }^{3}$ \\ ${ }^{1}$ Department of Nutrition, China Medical University, 91, Hsueh-Shih Road, Taichung, Taiwan \\ ${ }^{2}$ School of Medicine, Chung Shan Medical University, 110, Sec 1, Chien-kuo N Road, Taichung, Taiwan \\ ${ }^{3}$ Department of Biotechnology, Chang Jung Christian University, 396 Chang Jung Road, Sec 1, Kway Jen, Tainan, Taiwan
}

(Received 8 June 2006 - Revised 6 October 2006 - Accepted 6 November 2006)

Expression of cell adhesion molecules by endothelium and the attachment of monocytes to endothelium may play a major role in atherosclerosis. Ellagic acid (EA) is a phenolic compound found in fruits and nuts including raspberries, strawberries, grapes and walnuts. Previous studies have indicated that EA possesses antioxidant activity in vitro. In the present study, we investigated the effects of EA on the formation of intracellular reactive oxygen species, the translocation of $\mathrm{NF \kappa B}$ and expression of vascular cell adhesion molecule-1 (VCAM-1), intercellular adhesion molecule- 1 and endothelial leucocyte adhesion molecule (E-selectin) induced by IL-1 $\beta$ in human umbilical vein endothelial cells (HUVEC). We found that EA significantly reduced the binding of human monocytic cell line, U937, to IL-1 $\beta$-treated HUVEC. The production of reactive oxygen species by IL- $1 \beta$ was dose-dependently suppressed by EA. Supplementation with increasing doses of EA up to $50 \mu \mathrm{mol} / 1$ was most effective in inhibiting the expression of VCAM-1 and E-selectin. Furthermore, the inhibition of IL-1 $\beta$-induced adhesion molecule expression by EA was manifested by the suppression of nuclear translocation of p65 and p50. In conclusion, EA inhibits IL-1 $\beta$-induced nuclear translocation of p65 and p50, thereby suppressing the expression of VCAM-1 and E-selectin, resulting in decreased monocyte adhesion. Thus, EA has anti-inflammatory properties and may play an important role in the prevention of atherosclerosis.

Ellagic acid: Cell adhesion molecule: NFкB: Reactive oxygen species: Atherosclerosis

Activation of the vascular endothelium, increased adhesion of mononuclear cells to the injured endothelial layer, and their subsequent extravasations into the vessel wall are initial events in atherogenesis. Endothelial cells recruit leucocytes by expressing adhesion molecules, such as vascular cell adhesion molecule-1 (VCAM-1), intercellular adhesion molecule-1 (ICAM-1) and endothelial leucocyte adhesion molecules (E-selectin; Cybulsky \& Gimbrone, 1991). Several inflammatory cytokines including IL-1, TNF and interferon produced by activated monocytes and macrophages may stimulate the endothelium to up-regulate genes encoding chemokines, other cytokines and adhesion molecules (Ross, 1999).

Previous studies have indicated that NF- $\mathrm{B} /$ Rel transcription factors may play an important role in the development of atherosclerosis (Collins, 1993; Qwarnstrom et al. 1994). Activation of NF- $\mathrm{BB}$ by inflammatory stimuli has been demonstrated in cultures of endothelial cells using electrophoretic mobility shift assays (Collins, 1993). A variety of genes induced in the atherosclerotic lesion have been shown to be regulated by NF- $\kappa \mathrm{B}$ proteins, including the genes encoding TNF- $\alpha$ (Baeuerle \& Henkel, 1994), IL-1 $\beta$ (Hiscott et al. 1993), VCAM-1 (Neish et al. 1992) and ICAM-1 (Poston et al. 1992).
It is well established that dietary polyphenolic compounds play significant roles in the prevention of atherosclerosis and CVD (Gaziano et al. 1992; Gey et al. 1993). Polyphenolic compounds affect the development of atherosclerosis not only through modulation of serum lipids but also by influencing the immune and inflammatory processes associated with the development of this disease. Previous studies have indicated that polyphenolic compounds such as vitamin $\mathrm{E}$ or tea flavonoid may exert their effects through modulation of cytokines, adhesion molecules and interaction of immune cells with endothelial cells (Martin et al. 1997; Islam et al. 1998; Ludwig et al. 2004). Ellagic acid (EA) is a phenolic compound found in fruits including grape juice $(10.2 \mathrm{mg} / 100 \mathrm{~g})$, grape wine $(5.6 \mathrm{mg} / 100 \mathrm{~g})$, blueberries $(0.9 \mathrm{mg} /$ $100 \mathrm{~g})$, blackberries $(42.4 \mathrm{mg} / 100 \mathrm{~g})$, raspberries $(17.9 \mathrm{mg} /$ $100 \mathrm{~g}$ ) and strawberries $(19.8 \mathrm{mg} / 100 \mathrm{~g})$ (de Ancos et al. 2000; Sellappan et al. 2002; Mertens-Talcott et al. 2003). Previous studies have indicated that EA scavenges both oxygen and hydroxyl radicals, and inhibits lipid peroxidation (Cozzi et al. 1995; Laranjinha et al. 1996; Iino et al. 2001). In our laboratory, we found that EA reduced oxidative stress and atherosclerosis in a hyperlipidaemic rabbit model (Yu et al. 2005). Therefore, the present study was designed to examine the effect of EA on monocyte adhesion to cultured human endothelial cells and the

Abbreviations: EA, ellagic acid; E-selectin, endothelial leucocyte adhesion molecule; HUVEC, human umbilical vein endothelial cell; ICAM-1, intercellular adhesion molecule-1; MTT, 3-(4,5-dimethylthiazol-2-yl)-2,5-diphenyl tetrazolium bromide; VCAM-1, vascular cell adhesion molecule-1.

*Corresponding author: Dr Ya-Mei Yu, fax +886 4 22083762, email ymyu@mail.cmu.edu.tw 
expression of adhesion molecules (VCAM-1, ICAM-1 and Eselectin) and to elucidate its possible mechanism.

\begin{abstract}
Methods

\section{Cell culture}

Human umbilical vein endothelial cells (HUVEC) were isolated by collagenase type II (Biochrom KG, Berlin, Germany) digestion of human umbilical veins by standard techniques and cultured in EC medium (MCDB 131; Gibco-BRL, Life Technologies $\mathrm{GmbH}$, Karlsruhe, Germany) at $37^{\circ} \mathrm{C}$ in a humidified atmosphere of $5 \% \mathrm{CO}_{2}$ and $95 \%$ air as described previously (Stangl et al. 2001). All experiments were performed with HUVEC from passages one to three. HUVEC were seeded at $1 \times 10^{4}$ cells/well in ninety-six-well plates. After $3 \mathrm{~d}$, the medium was replaced by fresh EC medium before treatment.
\end{abstract}

\section{Cell viability assay using 3-(4,5-dimethylthiazol-2-yl)-2, 5-diphenyl tetrazolium bromide}

Cell viability was measured by 3-(4,5-dimethylthiazol-2-yl)2,5-diphenyl tetrazolium bromide (MTT) assay (Chen et al. 2002). The principle of this assay is that mitochondria dehydrogenase in viable cells reduces MTT to a blue formazan. Briefly, cells were grown in ninety-six-well plates and incubated with various concentrations of EA (which was dissolved in dimethyl sulphoxide) for $24 \mathrm{~h} ; 100 \mu \mathrm{l}$ MTT $(0.5 \mathrm{mg} / \mathrm{ml})$ were then added to each well and incubation continued at $37^{\circ} \mathrm{C}$ for an additional $4 \mathrm{~h}$. The medium was then carefully removed, so as not to disturb the formazan crystals which had formed. Dimethyl sulphoxide $(100 \mu \mathrm{l})$, which solubilizes formazan crystals, was added to each well and the absorbance of the solubilized blue formazan was read at $530 \mathrm{nml} / 1$ (reaction) and $690 \mathrm{nml} / 1$ (background) using a DIAS Microplate Reader (Dynex Technologies, Chantilly, VA, USA). The reduction in optical density caused by EA was used as a measurement of cell viability, normalized to cells incubated in control medium, which were considered $100 \%$ viable.

\section{Estimation of the production of reactive oxygen species}

The production of intracellular reactive oxygen species (ROS) induced by IL-1 $\beta$ was estimated by a fluorometric assay using $2^{\prime}, 7^{\prime}$-dichlorofluorescein-diacetate (DCFH-DA) as a probe according to the method reported by Bass et al. (1983). $\operatorname{HUVEC}\left(1 \times 10^{6}\right)$ were incubated with IL- $1 \beta$ and EA, suspended in PBS containing $2 \%$ fetal calf serum, and then incubated again with $5 \mathrm{mmol} / 12^{\prime}, 7^{\prime}$-dichlorofluorescein-diacetate for $30 \mathrm{~min}$ at $37^{\circ} \mathrm{C}$. The formation of $2^{\prime}, 7^{\prime}$-dichlorofluorescein was determined by flow cytometry. The excitation wavelength was $488 \mathrm{~nm}$, and green fluorescence collected through a $530 \mathrm{~nm}$ band-pass filter was measured on a logarithmic scale. The formation of ROS was expressed as relative fluorescence intensity.

\section{Real-time PCR for vascular cell adhesion molecule-1, intercellular adhesion molecule-1 and endothelial leucocyte adhesion molecule}

The real-time PCR assay for adhesion molecules was conducted according to the method reported by $\mathrm{Li} \&$ Wang
(2002). Total cellular RNA was isolated from samples (HUVEC) using the Trizol reagent according to the manufacturer's instructions (Gibco BRL). RT reactions were carried out for each RNA sample in thin-welled PCR tubes using the First-Strand Synthesis System (Invitrogen, Carlsbad, CA, USA). Each reaction tube contained $4 \cdot 2 \mu \mathrm{g}$ total RNA in a volume of $21 \mu \mathrm{g}$ containing $1 \times \mathrm{RT}$ buffer, $5.5 \mathrm{mmol} / \mathrm{l}$ $\mathrm{MgCl}_{2}, 500 \mu \mathrm{mol} / 1$ of each $\mathrm{dNTP}, 2.5 \mu \mathrm{mol} / \mathrm{l}$ of oligo$\mathrm{d}(\mathrm{T})_{12-18}$ primers, $40 \mathrm{U} / \mu \mathrm{l}$ RNase inhibitor, $2 \mathrm{U} / \mu \mathrm{l}$ Escherichia coli $\mathrm{RNaseH}$ and $50 \mathrm{U} / \mu \mathrm{l}$ of SuperScript II RT. RT reaction was carried out at $65^{\circ} \mathrm{C}$ for $5 \mathrm{~min}, 42^{\circ} \mathrm{C}$ for $50 \mathrm{~min}$ and $70^{\circ} \mathrm{C}$ for $15 \mathrm{~min}$. The $\mathrm{RT}$ reaction mixture was then placed at $4^{\circ} \mathrm{C}$ for immediate PCR amplification or stored at $-20^{\circ} \mathrm{C}$ for later use. Real-time PCR was performed in optical realtime PCR tubes. The following primers were used: VCAM1: forward 5'-AAGCGGAGACAGGAGACAC-3', reverse 5'TGGCAGGTATTATTAAGGAGGATG-3' ${ }^{\prime}$;CAM-1: forward 5'-TGGTTCACAGGTTCAGATTAC-3', reverse 5'-GACAAGAGGACAAGGCATAGC-3'; E-selectin: forward 5'-TGTGAGATGCGATGCTGTC- $3^{\prime}$, reverse $5^{\prime}$-AACCTCTTCTGTCCATTGTCC-3'; glyceraldehyde-3-phosphate dehydrogenase: forward $5^{\prime}$-CCCACTCCTCCACCTTTG-3', reverse 5'-CTTCCTCTTGTGCTCTTGC-3'.

Each tube contained $1 \mu \mathrm{l}$ of each RT product (200 ng total RNA), $5.5 \mathrm{mmol} / 1 \mathrm{MgCl}_{2}, 400 \mu \mathrm{M}$-dNTP, $500 \mathrm{nmol} / \mathrm{l}$ primer (forward and reverse), $0.005 \mathrm{U} / \mu \mathrm{l}$ iTaq DNA polymerase and $20 \mathrm{nmol} / \mathrm{l} \mathrm{SYBR}$ Green I in a total volume of $25 \mu \mathrm{l}$. Amplification conditions were $3 \mathrm{~min}$ at $95^{\circ} \mathrm{C}$ for activation, then run for forty cycles at $95^{\circ} \mathrm{C}$ for $15 \mathrm{~s}$ and $60^{\circ} \mathrm{C}$ for $1 \mathrm{~min}$. All reactions were performed in the Bio-Rad iCycle Sequence Detection System using the iCycle V3.1 program. The threshold cycle $(\mathrm{Ct})$ and melting point $(\mathrm{Mt})$ were obtained during each reaction. The relative quantification was calculated based on its $2^{-\Delta C t}$ value, $\Delta C t=C t$ (sample) $-C t$ (control).

\section{Measurement of $N F-\kappa B$ activity}

Nuclear extracts were prepared as described previously (Dschietzig et al. 2001). Bradford reagent determined protein concentrations. For analysis of NF- $\kappa \mathrm{B}$ activity, a TransAM NF-кB Family kit was used (Active Motif, Rixensart, Belgium). In this assay, ninety-six-well plates were coated with an oligonucleotide containing the consensus binding sequence for NF- $\kappa$ B 5'-GGGACTTTCC-3'. Specific primary antibodies included in the kit detected the binding of NF$\kappa \mathrm{B}$ family transcription factors to their consensus sequence. Experiments were analysed by an ELISA-based assay. A total of $10 \mu \mathrm{g}$ nuclear extract was used in each experiment and processed according to the manufacturer's protocol. Briefly, nuclear extracts were incubated with the oligonucleotide-coated wells for $60 \mathrm{~min}$. Where indicated a competitor for NF- $\kappa \mathrm{B}$ binding (NF- $\kappa \mathrm{B}$ wild-type consensus oligonucleotide) was added in molar excess prior to the probe. The wells were then washed and incubated with the primary antibodies for p65, p50, c-Rel, p52 and RelB for $60 \mathrm{~min}$. After incubation with a horseradish peroxidase-conjugated secondary antibody, a substrate was added to produce blue colour and then for quantitation by a standard ELISA reader. The absorbance was read at $450 \mathrm{~nm}$ and the blanks were subtracted from all measurements. The data presented are the result of three independent experiments. 


\section{Monocyte-endothelial cell adhesion}

HUVEC $\left(2 \times 10^{5}\right)$ were distributed into six-well plates and allowed to reach confluence. They were then incubated for $18 \mathrm{~h}$ with medium supplemented with EA at concentrations of 25 and $50 \mu \mathrm{mol} / 1$ according to the MTT test, followed by incubation for $6 \mathrm{~h}$ with $10 \mathrm{ng} / \mathrm{ml} \mathrm{IL}-1 \beta$ in the continued presence of EA. U937 cells, originally derived from a human histiocytic lymphoma and used for the monocyteendothelial cell adhesion assay, were grown in RPMI-1640 medium (Gibco, New York, USA) containing 10\% fetal bovine serum and subcultured at a $1: 5$ ratio three times per week, labelled for $30 \mathrm{~min}$ at $37^{\circ} \mathrm{C}$ with calcein $\mathrm{AM}$ (10 nmol/l; Molecular Probe; Invitrogen) in RPMI-1640 medium and washed with PBS to remove free dye, and then resuspended in $10 \% \mathrm{M}-199$ medium. Labelled U937 cells $\left(1 \times 10^{6}\right)$ were added to each HUVEC-containing well and incubated for $1 \mathrm{~h}$. Non-adherent cells were removed by two gentle washes with PBS. Then, adherent U937 cells were determined by a fluorescence plate reader at an excitation wavelength of $485 \mathrm{~nm}$ and emission at $530 \mathrm{~nm}$; HUVEC cell monolayers served as the blank.

\section{Statistics}

Results are presented as means and standard deviations. Statistical significance was determined by one-way ANOVA. Differences were considered significant at $P<0 \cdot 05$.

\section{Results}

Concentrations of ellagic acid for human umbilical vein endothelial cells

Cell viability was assayed by the MTT test. After $24 \mathrm{~h}$ incubation with $10,25,50,75,100$ and $150 \mu \mathrm{mol} / \mathrm{l} \mathrm{EA}$, cell viability was $125 \cdot 2$ (SD 4.9), 122.3 (SD 4.4), 106.7 (SD 2.7), 91.3 (SD 1.8), 75.8 (SD 1.4) and 78.4 (SD 1.4) \%, respectively, of control levels, the three highest concentrations causing a significant reduction in cell viability. Therefore, according to the MTT test we chose 25 and $50 \mu \mathrm{mol} / 1$ to do all the experiments.

\section{Ellagic acid inhibits $I L-1 \beta$-induced reactive oxygen species production in human umbilical vein endothelial cells}

Fig. 1(A) shows the results of ROS production induced by IL-1 $\beta$. The production of ROS decreased after addition of 25 and $50 \mu \mathrm{mol} / \mathrm{l} \mathrm{EA} \mathrm{(Fig.} \mathrm{1(B,} \mathrm{C)).}$

Ellagic acid inhibits IL-1 $\beta$-induced cell surface expression of vascular cell adhesion molecule-1 and endothelial leucocyte adhesion molecule but not expression of intercellular adhesion molecule-1 in human umbilical vein endothelial cells

The effects of EA on IL-1 $\beta$-induced VCAM-1, ICAM-1 and E-selectin expression by HUVEC were studied by pretreating HUVEC for $18 \mathrm{~h}$ with 25 or $50 \mu \mathrm{mol} / 1 \mathrm{EA}$ before addition of $10 \mathrm{ng} / \mathrm{ml}$ IL-1 $\beta$. This resulted in reduced cell surface expression of VCAM-1 and E-selectin, but had no effect on cell surface expression of ICAM-1 (Fig. 2(A-C)).
Ellagic acid attenuates activation of $N F-\kappa B$ expression and nuclear translocation of $N F-\kappa B$ p65 and p50 in $I L-1 \beta$-stimulated human umbilical vein endothelial cells

To examine whether the inhibitory effect of EA on the cytokineinduced expression of adhesion molecules is medicated via NF$\kappa \mathrm{B}$, we measured the nuclear translocation of $\mathrm{p} 65$ and $\mathrm{p} 50$ protein of the NF- $\kappa \mathrm{B}$ family of transcription factors. Incubation of IL-1 $\beta$ $(10 \mathrm{ng} / \mathrm{ml})$ for $6 \mathrm{~h}$ induced the nuclear translocation of p65 and p50 (Fig. 3(A, B)). Preincubation of HUVEC with $50 \mu \mathrm{mol} / \mathrm{l}$ EA prior to IL-1 $\beta$ stimulation did significantly prevent the nuclear translocation of p65 and p50 (Fig. 3(A, B)).
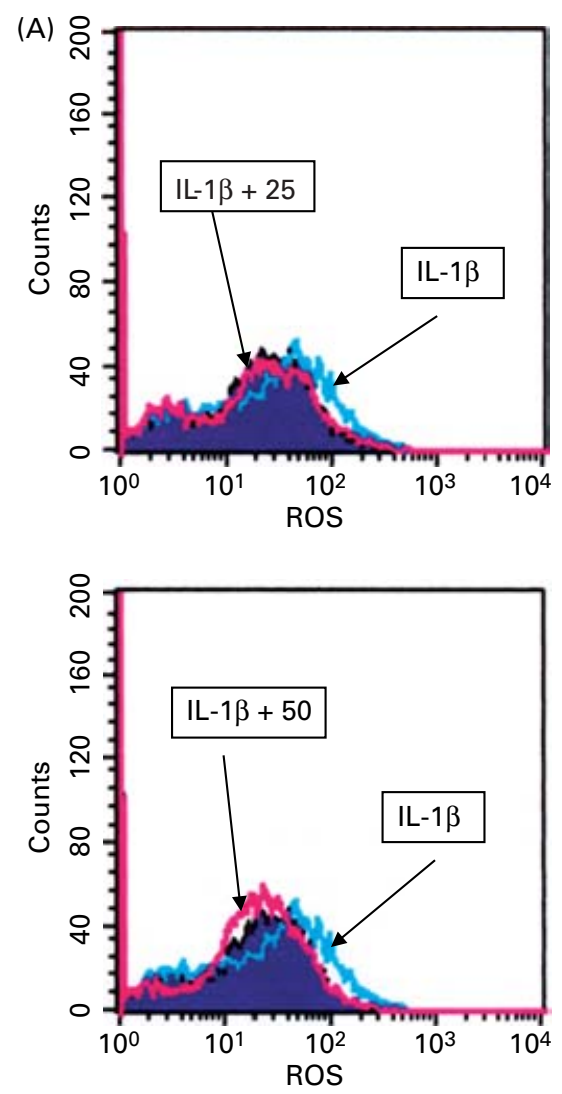

(B)

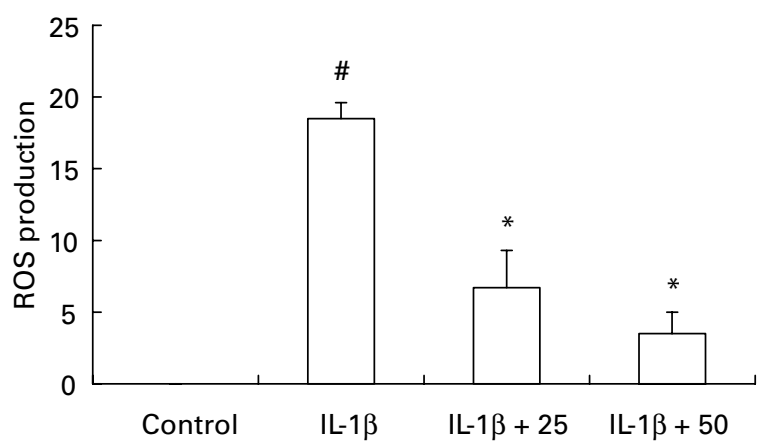

Fig. 1. Effect of ellagic acid on IL-1 $\beta$-induced reactive oxygen species (ROS) production in human umbilical vein endothelial cells (HUVEC). HUVEC were stimulated with IL-1 $\beta$ after preincubation with 25 (IL-1 $\beta+25)$ and 50 (IL$1 \beta+50) \mu \mathrm{mol} / /$ ellagic acid. HUVEC were labelled with $\mathrm{H}_{2} \mathrm{O}_{2}$-sensitive fluorescent probe and were detected by flow cytometry (A). Mean ROS production was expressed as \% of control $(n$ 3) (B). Mean values were significantly different from those of the control group: \#P<0.05. Mean values were significantly different from those of the IL-1 $\beta$ group: ${ }^{\star} P<0.05$. 
(A)

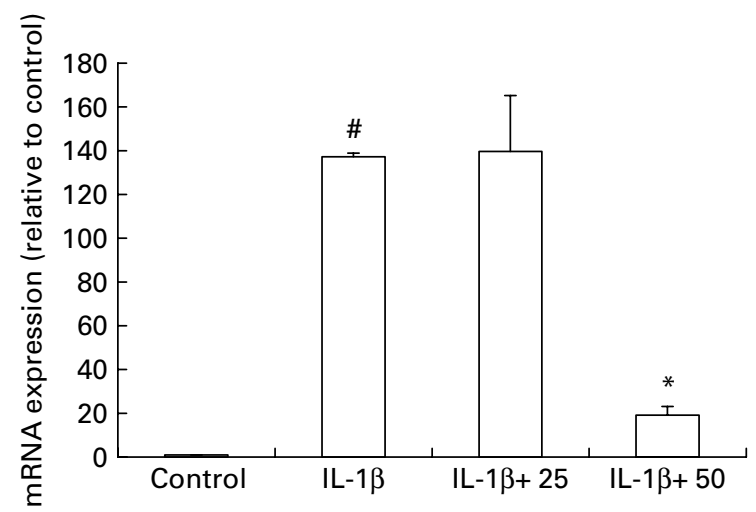

(B)

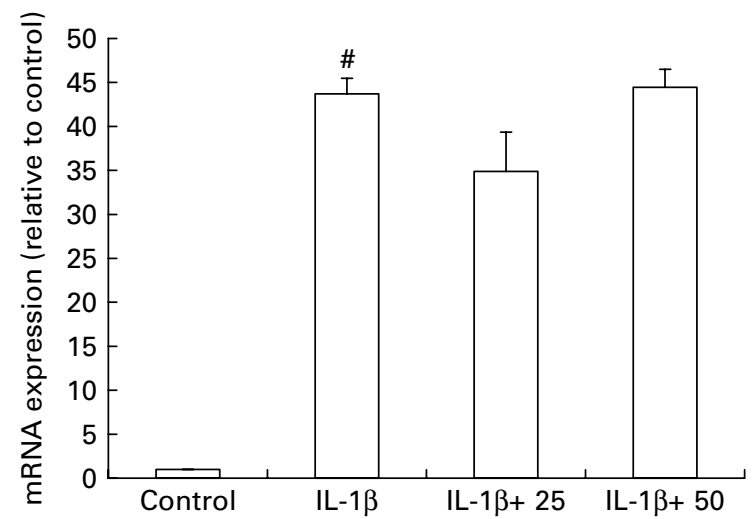

(C)

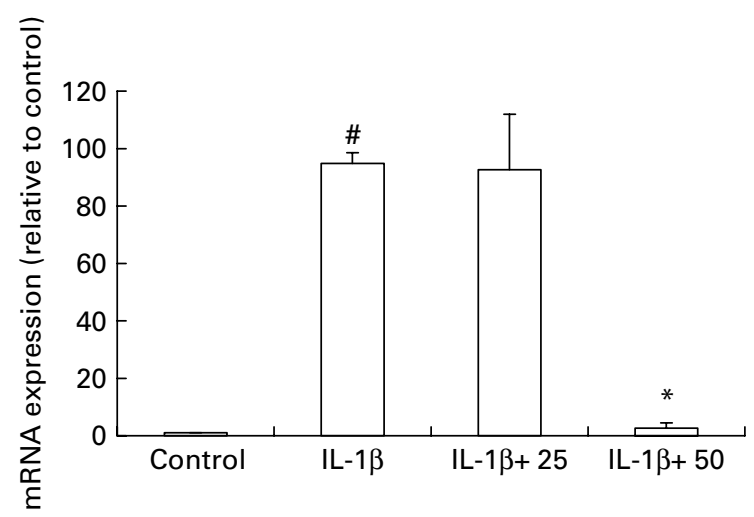

Fig. 2. Effect of ellagic acid on the expression of vascular cell adhesion molecule-1 (VCAM-1), intercellular adhesion molecule-1 (ICAM-1) and E-selectin in human umbilical vein endothelial cells (HUVEC). HUVEC were pretreated $25(\mathrm{IL}-1 \beta+25)$ and $50(\mathrm{IL}-1 \beta+50) \mu \mathrm{mol} / /$ ellagic acid for $18 \mathrm{~h}$ and then induced by IL-1 $\beta$ for $6 \mathrm{~h}$. The expression of VCAM-1 (A), ICAN-1 (B) and endothelial leucocyte adhesion molecule (E-selectin) (C) were measured by real-time PCR. Values are means with their standard deviations depicted by vertical bars $(n 3)$. Mean values were significantly different from those of the control group: $\# P<0.05$. Mean values were significantly different from those of the IL-1 $\beta$ group: ${ }^{*} P<0.05$.

Ellagic acid inhibits adhesion of U937 cells to IL-1 $\beta$-stimulated human umbilical vein endothelial cells

To explore the effects of EA on endothelial cell leucocyte interactions, we examined the adhesion of U937 cells to
(A)

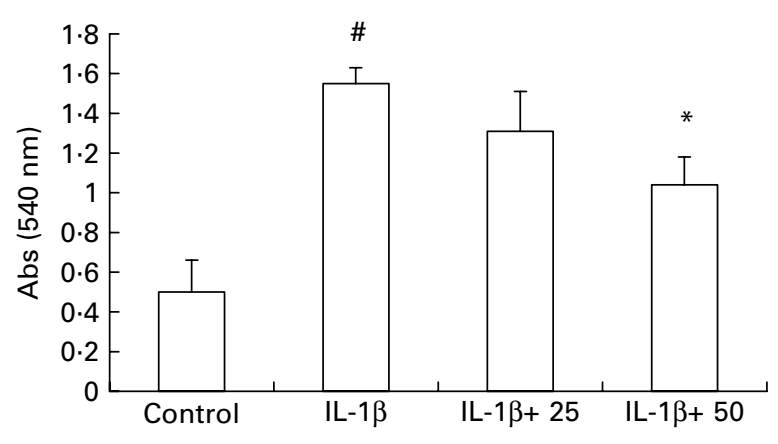

(B)

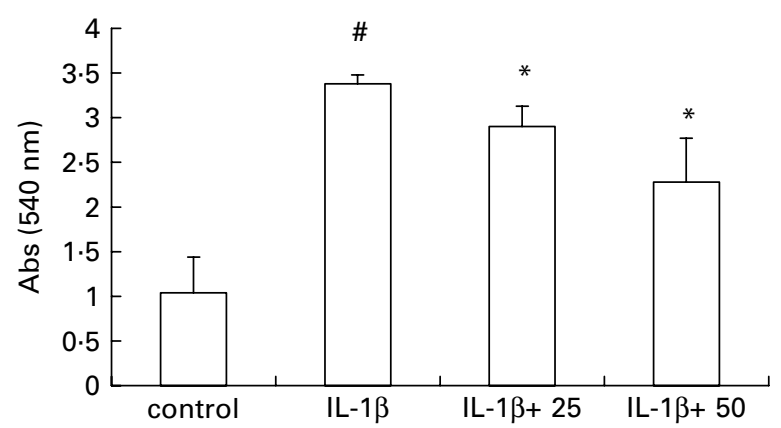

Fig. 3. Effect of ellagic acid on IL-1 $\beta$-induced activation of NF-kB $p-65(A)$ and $p-50$ (B). Human umbilical vein endothelial cells (HUVEC) were pretreated with $25(\mathrm{IL}-1 \beta+25)$ and $50(\mathrm{IL}-1 \beta+50) \mu \mathrm{mol} / \mathrm{l}$ ellagic acid for $18 \mathrm{~h}$ and induced by IL-1 $\beta(10 \mathrm{ng} / \mathrm{ml})$ for $6 \mathrm{~h}$. Nuclear extracts were prepared and analysed for activation of NF-кB family. Five micrograms of nuclear protein was used in each experiment. Values are means with their standard deviations depicted by vertical bars $(n 3)$. Mean values were significantly different from those of the control group: $\# P<0.05$. Mean values were significantly different from those of the IL-1 $\beta$ group: ${ }^{\star} P<0.05$.

cytokine-activated HUVEC. Control confluent HUVEC showed minimal binding to U937 cells, but adhesion increased when the HUVEC were treated with IL-1 $\beta$ (Fig. 4(A, B)). Pretreatment of HUVEC with $50 \mu \mathrm{mol} / \mathrm{l}$ EA reduced the number of U937 cells adhering to IL-1 $\beta$-stimulated HUVEC (Fig. 4(A, B)).

\section{Discussion}

An early stage in atherosclerosis is the adhesion of monocytes to the arterial wall, followed by their infiltration and differentiation into macrophages. This key stage is mediated by the interaction of monocytes with adhesion molecules expressed by endothelial cells. In the present study, we found that $50 \mu \mathrm{mol} / 1 \mathrm{EA}$ treatment $(50 \mu \mathrm{mol} / \mathrm{l} \mathrm{EA}$ is equivalent to the dietary intake of approximately $200 \mathrm{~g}$ blackberries or $350 \mathrm{~g}$ strawberries; Walgren et al. 1998; Mertens-Talcott et al. 2003; Whitley et al. 2003) effectively blocked VCAM-1 and E-selectin expression in IL-1 $\beta$-induced HUVEC. It significantly reduced the binding of human monocytic cell line U937 to IL-1 $\beta$-induced HUVEC. Previous studies also 
(A)

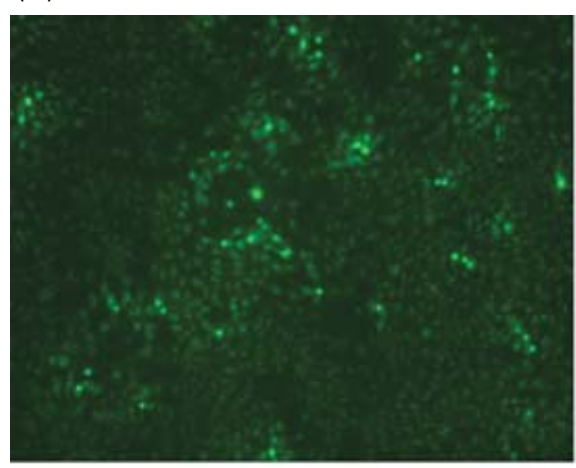

$\mathrm{IL}-1 \beta+25$

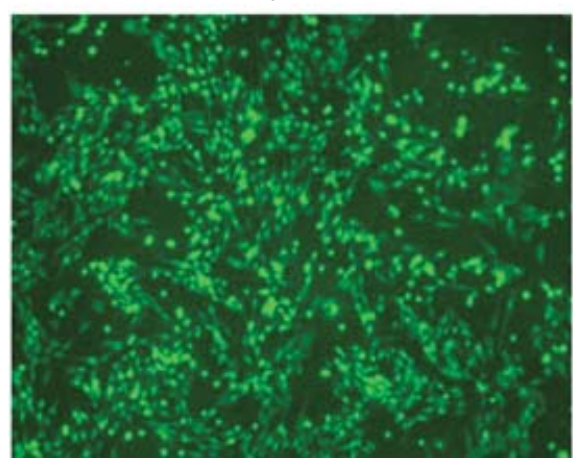

IL-1 $\beta$

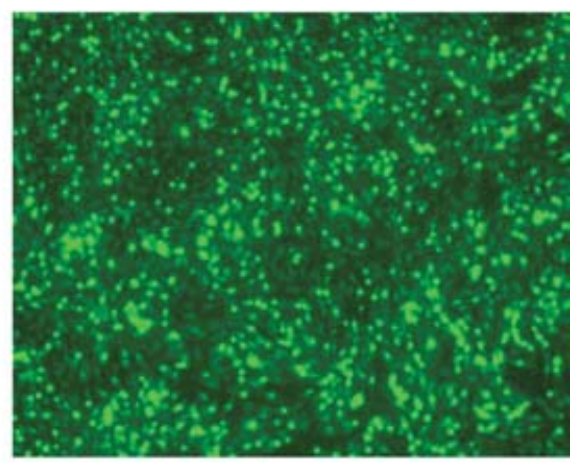

$\mathrm{IL}-1 \beta+50$

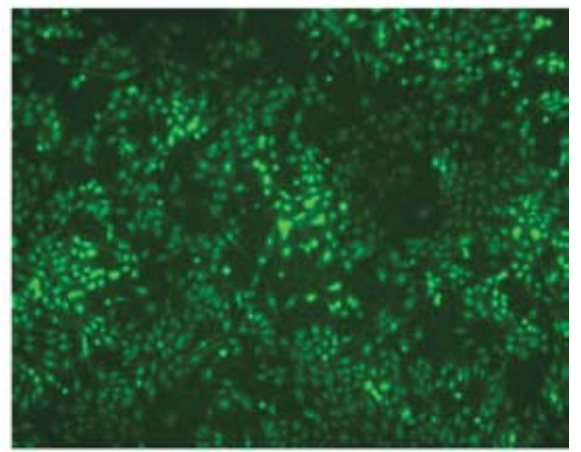

(B)

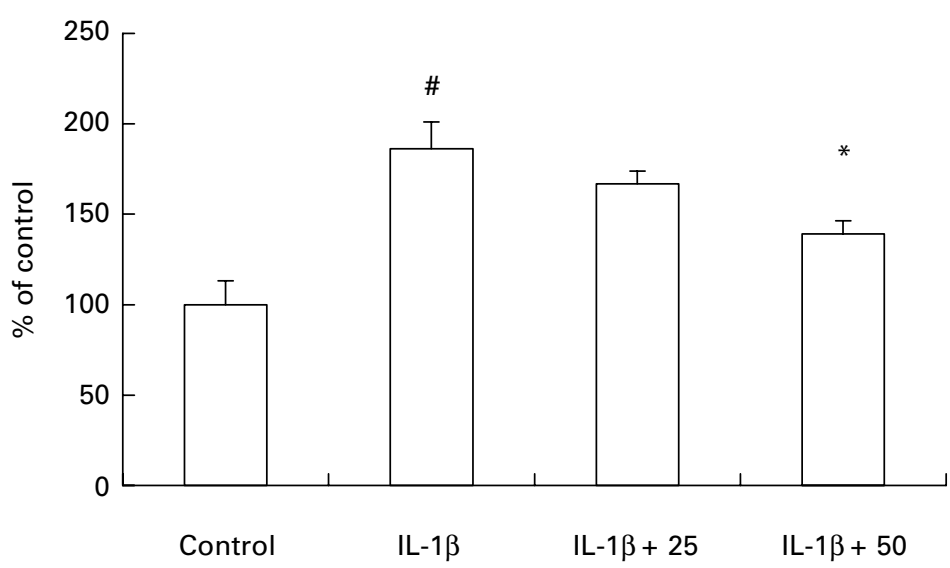

Fig. 4. Reduction effect of ellagic acid on IL-1 $\beta$-induced adhesion of U937 cells to human umbilical vein endothelial cells (HUVEC). (A), Representative images of the reduction of IL-1 $\beta$-induced adhesion of U937 cells to HUVEC monolayers after pretreatment of 25 (IL-1 $\beta+25)$ and 50 (IL-1 $\beta+50) \mu \mathrm{mol} / \mathrm{l}$ ellagic acid for 18h. (B), HUVEC were pretreated with 25 (IL-1 $\beta+25)$ and 50 (IL-1 $\beta+50) \mu \mathrm{mol} / /$ ellagic acid for $18 \mathrm{~h}$ and induced by IL-1 $1 \beta$ (10 ng/ml) for $6 \mathrm{~h}$. Fluorescencelabelled U937 cells were added to the HUVEC monolayer and allowed to adhere for $30 \mathrm{~min}$. Values are means with their standard deviations depicted by vertical bars $(n$ 3). Mean values were significantly different from those of the control group: $\# P<0.05$. Mean values were significantly different from those of the IL-1 $\beta$ group: ${ }^{*} P<0.05$.

showed that other polyphenolic compounds, such as vitamin $\mathrm{E}$ ( $40 \mu \mathrm{mol} / \mathrm{l})$, probucol $(50 \mu \mathrm{mol} / \mathrm{l})$ or tea flavonoid $(60 \mu \mathrm{mol} / \mathrm{l}$ epigallocatechin-3-gallate), reduce cytokine-induced adhesion molecule expression and monocyte adhesion to endothelial cells (Islam et al. 1998; Zapolska-Downar et al. 2001; Ludwig et al. 2004). In the present study, EA reduced cytokine-induced expression of VCAM-1 and E-selectin but not ICAM-1. A similar result was seen when HUVEC were pretreated with probucol; probucol reduced IL-1 $\beta$-induced VCAM-1 surface protein and mRNA expression, but not ICAM-1 expression (Zapolska-Downar et al. 2001). Previous studies indicated that VCAM-1, but not ICAM-1, plays a critical role in the initiation of atherosclerosis (Cybulsky et al. 2001). VCAM-1 is expressed in vascular lesions in early atherosclerosis and has been found to be elevated in serum from patients with early atherosclerosis, suggesting that this adhesion protein is one of the key molecules involved in the atherogenic process (Cybulsky \& Gimbrone, 1991; Rohde et al. 1998).

The NF- $\mathrm{BB}$ family controls the expression of genes involved in the inflammation and immune response (Baeuerle, 1991). In the cytoplasm, inactive NF- $\mathrm{KB}$ exists as a heterodi- 
meric complex of subunits p50 and p65 that binds to a cytoplasmic protein, ІкB (Baeuerle \& Henkel, 1994). Upon activation, $\mathrm{I} \kappa \mathrm{B}$ is rapidly degraded, and the p50/p65 heterodimer is translocated from the cytoplasm into the nucleus where the dimer interacts with regulatory $\kappa \mathrm{B}$ elements in promoters and enhancers, thereby controlling gene transcription (Baeuerle \& Baltimore, 1988; Grilli et al. 1993; Chenbg et al. 1994). NF- $\mathrm{B}$ is activated by a multitude of stimuli, including inflammatory cytokines and reactive oxygen intermediates (Baeuerle \& Baltimore, 1988; Grilli et al. 1993; Chenbg et al. 1994; Muller et al. 1997), which are activated in atherosclerotic lesions (Brand et al. 1996; Barnes \& Karin, 1997; D’ Acquisto et al. 2002). In the present study, we demonstrated that EA reduced cytokine-induced expression of VCAM-1 and E-selectin and prevented the nuclear translocation of p65 and p50 in endothelial cells. The present results suggest that the inhibitory mechanisms of EA might interrupt a signalling cascade involving VCAM transcription-mediated activation of NF- $\kappa$ B.

Several studies have indicated that ROS are implicated in the activation of NF-кB (Muller et al. 1997). The current study shows that the ROS production stimulated by IL-1 $\beta$ was decreased by EA pretreatment (Fig. 2(A-C)). Based on the present result, we propose that the inhibitory effect of EA on VCAM-1 expression and NF- $\mathrm{KB}$ activation may be due to its antioxidant properties and that it may act by directly scavenging free radicals. In one of our previous studies, we found that EA is approximately 2-3-fold more potent than Trolox in antioxidative ability. Our previous results showed that it scavenged $\alpha$ - $\alpha$-diphenol- $\beta$-picrylhydrazyl (DPPH), alkoxyl radical $\left(\mathrm{RO}^{\circ}\right)$ and peroxyl radical $\left(\mathrm{ROO}^{\circ}\right)$ and inhibited LDL oxidation ( $\mathrm{Yu}$ et al. 2005). Since atherosclerosis is a chronic inflammatory disease associated with increased oxidative stress in the vascular endothelium, it would be conceivable that the anti-atherogenic effects of EA might due to its antioxidative properties. The inhibition of cytokine-induced VCAM-1 expression has been described for other substances with antioxidant properties such as tea flavonoid epigallocatechin-3-gallate, probucol, magnolol, protocatechuic aldehyde and other flavonoids (Zapolska-Downar et al. 2001; Chen et al. 2002; Ludwig et al. 2004; Zhou et al. 2005).

In conclusion, EA inhibits IL- $1 \beta$-induced VCAM- 1 and Eselectin expression in HUVEC through a mechanism that involves NF- $\kappa \mathrm{B}$. It reduces the binding of human monocytic cell line U937 to IL-1 $\beta$-induced HUVEC, which might be due to its antioxidant properties.

\section{Acknowledgements}

The research was supported by grants from the National Science Counsel of Taiwan (NSC 93-2320-B-039-017) and China Medical University (CMU 93-NT-01).

\section{References}

Baeuerle PA (1991) The inducible transcription activator NFкB: regulation by distinct protein subunits. Biochim Biophys Acta 1072, 63-80.

Baeuerle PA \& Baltimore D (1988) ІкB: a specific inhibitor of the NFkB transcription factor. Science 242, 540-546.
Baeuerle PA \& Henkel T (1994) Function and activation of NF-кB in the immune system. Annu Rev Immunol 12, 141-179.

Barnes PJ \& Karin M (1997) Nuclear factor-kappa B: a pivotal transcription factor in chronic inflammatory diseases. $N$ Engl $\mathrm{J} \mathrm{Med}$ 336, 1066-1071.

Bass DA, Parce JW, Decharelet LR, Szejda P, Seeds MC \& Thomas M (1983) Flow cytometric studies of oxidative product formation by neutrophils: a graded response to membrane stimulation. J Immunol 130, 1910-1917.

Brand K, Page S, Rogler G, Bartsch A, Brandl R, Knuechel R, Page M, Kalschmidt C, Baeuerle PA \& Neumeier D (1996) Activated transcription factor nuclear factor-kappa B is present in the atherosclerotic lesion. J Clin Invest 97, 1715-1722.

Chen YH, Lin SJ, Chen JW, Ku HH \& Chen YL (2002) Magnolol attenuates VCAM-1 expression in vitro in TNF- $\alpha$-treated human aortic endothelial cells and in vivo in the aorta of cholesterol-fed rabbits. Br J Pharmacol 135, 37-47.

Chenbg Q, Cant CA, Moll T, Hofer-Warbinek R, Wagner E, Birnstiel ML, Bach FH \& de Martin R (1994) NF-кB subunit-specific regulation of the I kappa B-alpha promoter. J Biol Chem 296, $13551-13557$.

Collins T (1993) Biology of disease: endothelial nuclear factor- $\kappa \mathrm{B}$ and the initiation of the atherosclerotic lesion. Lab Invest $\mathbf{6 8}$, 499-508.

Cozzi R, Ricordy R, Bartolini F, Ramadori L, Perticone P \& De Salvia R (1995) Taurine and ellagic acid: two differently-acting natural antioxidants. Environ Mol Mutagen 26, 248-254.

Cybulsky MA \& Gimbrone J (1991) Endothelial expression of a mononuclear leukocyte adhesion molecule during atherogenesis. Science 251, 788-791.

Cybulsky MI, Iiyama K, Li H, Zhu S, Chen M, Liyama M, Davis V, Gutierrez-Ramos JC, Connelly PW \& Milstone DS (2001) A major role for VCAM-1, but not ICAM-1, in early atherosclerosis. J Clin Invest 107, 1255-1262.

D'Acquisto F, May MJ \& Ghosh S (2002) Inhibition of nuclear factor kappa B (NF- $\mathrm{B})$ : an emerging theme in anti-inflammatory therapies. Mol Intervent 2, 22-35.

de Ancos B, Gonzalez EM \& Cano MP (2000) Ellagic acid, vitamin C and total phenolic contents and radical scavenging capacity affected by freezing and frozen storage in raspberry fruit. $J$ Agric Food Chem 48, 4565-4570.

Dschietzig T, Richter C, Pfannenschmidt G, Bartsch C, Laule M, Baumann G \& Stangl K (2001) Dexamethasone inhibits stimulation of pulmonary endothelins by proinflammatory cytokines: possible involvement of a nuclear factor $\mathrm{\kappa B}$ dependent mechanism. Intensive Care Med 27, 751-756.

Gaziano JM, Manson J, Buring JE \& Hennekens CH (1992) Dietary antioxidants and cardiovascular disease. Ann N Y Acad Sci 669, 249-259.

Gey KF, Stahelin HB \& Eichholser M (1993) Poor plasma status of carotene and vitamin $\mathrm{C}$ is associated with higher mortality from ischemic heart disease and stroke: Panel Prospective Study. J Clin Invest 71, 3-6.

Grilli M, Chiu JJS \& Lenardo MJ (1993) NFкB and Rel: participants in a multiform transcriptional regulatory system. Int Rev Cytol 143, $1-62$.

Hiscott J, Marois J, Garoufalis J, et al. (1993) Characterization of a functional NF-kappa B site in the human interleukin-1 $\beta$ promoter: evidence for a positive autoregulatory loop. Mol Cell Biol 13, $6231-6240$.

Iino T, Nakahara K, Miki W, Kiso Y, Ogawa Y, Kato S \& Takeuchi $\mathrm{K}$ (2001) Less damaging effect of whisky in rat stomachs in comparison with pure ethanol. Role of ellagic acid, the nonalcoholic component. Digestion 64, 214-221.

Islam KN, Devaraj S \& Jialal I (1998) alpha-Tocopherol enrichment of monocytes decrease agonist-induced adhesion to human endothelial cells. Circulation 98, 2255-2261. 
Laranjinha J, Vierira O, Almeida L \& Madeira V (1996) Inhibition of metmyoglobin $/ \mathrm{H}_{2} \mathrm{O}_{2}$-dependent low density lipoprotein lipid peroxidation by naturally occurring phenolic acid. Biochem Pharmacol 51, 395-402.

Li X \& Wang X (2002) Application of real-time polymerase chain reaction for the quantitation of interleukin-1 $\beta$ mRNA upregulation in brain ischemic tolerance. Brain Res Protocols 5, 211-217.

Ludwig A, Lorenz M, Grimbo N, Steinle F, Meiners S, Bartsch C, Stangl K, Baumann G \& Stangl V (2004) The tea flavonoid epigallocatechin-3-gallate reduces cytokine-induced VCAM-1 expression and monocyte adhesion to endothelial cells. Biochem Biophys Res Commun 316, 659-665.

Martin A, Foxall T, Blumberg JB \& Meydani M (1997) Vitamin E inhibits low density lipoprotein-induced adhesion of monocytes to human aortic endothelial cells in vitro. Arterioscler Thromb Vasc Biol 17, 429-436.

Mertens-Talcott SU, Talcott ST \& Percival SS (2003) Low concentrations of Quercetin and ellagic acid synergistically influence proliferation, cytotoxicity and apoptosis in MOLT-4 human leukemia cells. J Nutr 133, 2669-2674.

Muller JM, Rupec RA \& Baeuerle PA (1997) Study of gene regulation by NF-kappa B and AP-1 in response to reactive oxygen intermediates. Methods 11, 301-312.

Neish AS, Williams AJ, Palmer HJ, Whitley MZ \& Clollins T (1992) Functional analysis of the human vascular cell adhesion molecule1 promoter. J Exp Med 176, 1583-1593.

Poston RN, Haskard DO, Coucher JR, Gall NP \& Johnson-Tidey RR (1992) Expression of intercellular adhesion molecule-1 in atherosclerotic plaques. Am J Pathol 140, 665-673.

Qwarnstrom EE, Ostberg CO, Turk GL, Richardson CA \& Bomsztyk K (1994) Fibronectin attachment activates the NF- $\kappa B$ p50/p65 heterodimer in fibroblasts and smooth muscle cells. $J$ Biol Chem 269, 30765-30768.
Rohde LE, Lee RT, Rivero J, Jamacochian M, Arroyo LH, Briggs W, Rifai N, Libby P, Creager MA \& Ridker PM (1998) Circulating cell adhesion molecules are correlated with ultrasound-based assessment of carotid atherosclerosis. Arterioscler Thromb Vasc Biol 18, 1765-1770.

Ross R (1999) Atherosclerosis is an inflammatory disease. Am Heart $J$ 138, S419-S420.

Sellappan S, Akoh CC \& Krewer G (2002) Phenolic compounds and antioxidant capacity of Georgia-grown blueberries and blackberries. J Agric Food Chem 50, 2432-2438.

Stangl V, Gunther A, Jarrin A, Bramlage P, Moobed M, Staudt A, Baumann G \& Stangl K (2001) Homocysteine inhibits TNFalpha-induced endothelial adhesion molecule expression and monocyte adhesion via nuclear factor- $\mathrm{kB}$ dependent pathway. Biochem Biophys Res Commun 280, 1093-1100.

Walgren RA, Walle UK \& Walle T (1998) Transport of quercetin and its glucosides across human intestinal epithelial Caco-2 cells. Biochem Pharmacol 55, 1721-1727.

Whitley AC, Stoner GD, Darby MV \& Walle T (2003) Intestinal epithelial cell accumulation of the cancer preventive polyphenol ellagic acid - extensive binding to protein and DNA. Biochem Pharmacol 66, 907-915.

Yu YM, Chang WC, Wu CH \& Chiang SY (2005) Reduction of oxidative stress and apoptosis in hyperlipidemic rabbits by ellagic acid. J Nutr Biochem 16, 675-681.

Zapolska-Downar D, Zapolski-Downar A, Markiewski M, Diechanowicz A, Kaczmarczyk M \& Naruszewicz M (2001) Selective inhibition by probucol of vascular cell adhesion molecule-1 (VCAM-1) expression in human vascular endothelial cells. Atherosclerosis 155, $123-130$.

Zhou Z, Liu Y, Miao AD \& I Wang SQ (2005) Protocatechuic aldehyde suppresses TNF- $\alpha$-induced ICAM-1 and VCAM- 1 expression in human umbilical vein endothelial cells. Eur J Pharmacol 513, 1-8. 